\title{
Numerical and Experimental Modal Analysis of Wheels of Solaris 10 Solar Car and Parametric Design of Lightweight EV Wheel
}

\section{Solaris 10 Güneş Arabası Jantının Deneysel ve Teorik Modal Analizi ve Elektrikli Araç Jantının Parametrik Tasarım ile Hafifleştirilmesi}

\author{
Yasemin Nur Aydın 1,2*(D), Talha Batuhan Korkut 1,3 (D), Onur Özaydın 1 (D) ,Elvan

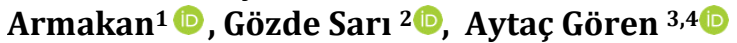 \\ ${ }^{1}$ Cevher Wheels / R\&D Department, İzmir, TURKEY \\ 2 Manisa Celal Bayar University /Department of Mechanical Engineering, Manisa, TURKEY \\ ${ }^{3}$ Dokuz Eylül University /Dept. of Mechanical Engineering, Automatic Control and Robotics Laboratories, İzmir, TURKEY \\ ${ }^{4}$ Université de Picardie Jules Verne / Laboratoire des Technologies Innovantes, Amiens, FRANCE \\ Sorumlu Yazar / Corresponding Author*: yaseminnuraydinn@gmail.com \\ Geliş Tarihi / Received: 14.09 .2020 \\ Araștırma Makalesi/Research Article \\ Kabul Tarihi / Accepted: 30.12.2020 \\ DOI:10.21205/deufmd.2021236829 \\ Atıf șekli/How to cite: AYDIN Y.N., KORKUT T.B., ÖZAYDIN O., ARMAKAN E., SARI G., GÖREN A. (2021). Numerical and Experimental Modal \\ Analysis of Wheels of Solaris 10 Solar Car and Parametric Design of Lightweight EV Wheel. DEÜFMD 23(68), 689-699.
}

\section{Abstract}

In this study, the natural frequencies of Solaris 10 Solar Car's 2018 and 2019-Model wheels were determined experimentally by the impact hammer test under free-free boundary conditions and the results were compared with the natural frequency results obtained using ANSYS FEA software. Comparing the numerical and experimental vibration analysis, a maximum percent error of $7.46 \%$ was observed. The 7th and upper mode frequencies of 2018 and 2019 wheel models were shown to be above $200 \mathrm{~Hz}$ and the experimental results were validated. After expressing the mode shapes in the ANSYS-Modal Analysis, a parametric study was performed for the 2019 wheel model using the ANSYS- Parametric Design. As a result of the parametric design, the mass of the 2019 wheel model was decreased by $6.5 \%$ while maximum equivalent von Mises stress was decreased by $2 \%$. Thus, a lighter wheel design was obtained with ANSYS FEA software and maximum equivalent von Mises stress value was achieved to be below pre-defined limit of 120 (MPa).

Keywords: Experimental Analysis, Impact hammer test, Modal analysis, Natural frequency, Wheel weight optimization, Parametric design

Öz

Bu çalışmada, dönmeyen lastiksiz Solaris 10 güneş arabası jantının 2018 ve 2019 modellerinin doğal frekansları, serbest sınır koşulları altında darbe çekici testi ile deneysel olarak belirlenmiş ve 
sonuçlar ANSYS Sonlu Elemanlar Analiz yazılımında elde edilen doğal frekans sonuçları ile karşılaștırılmıștır. Sayısal ve deneysel olarak elde edilen doğal frekans sonuçları karşılaștırıldığında, maksimum yüzde 7.46 hata elde edilmiștir. Deneysel olarak elde edilen sonuçlar doğrulanmış ve 2018 jant modeli ile 2019 jant modelinin 7. mod frekans ve üstü frekanslarının 200 Hertz'in üstünde olduğu gösterilmiştir. ANSYS- Modal Analiz modülünde gözlemlenen mod şekilleri, yüksek genlik oluşturabilecek doğal frekanslar için gösterilmiştir. 2019 Jant modeli için parametrik CAD modeli kullanılarak bir tasarım optimizasyonu çalışması gerçekleştirilmiştir. Tasarım optimizasyonu sonucunda 2019 jant modelinin kütlesi \% 6.5 azalırken, maksimum eşdeğer von Mises gerilmesi \% 2 azaltılmıștır. Böylelikle, ANSYS Sonlu elemanlar analizi yazılımında parametrik çalıșma ile daha hafif bir jant elde edilmiş ve maksimum eșdeğer von Mises gerilmesi 120 MPa'nın altında kalması sağlanmıştır.

Anahtar Kelimeler: Deneysel Analiz, Darbe çekici testi, Modal analiz, Doğal frekans, Jant ağırlık optimizasyonu, Parametrik tasarım

\section{Introduction}

One of the most important components of an automotive is the wheel which continues to evolve in alignment with the demand in the sector toward light-weighting and $\mathrm{R}$ \& $\mathrm{D}$ activities are rapidly increasing. The wheels have critical importance regarding fatigue damage, noise, and failure due to impact loads [1]. Determining the dynamic behaviour and vibration characteristics during driving is important to prevent excessive noise. The primary contributor to the vibration of a rim is it's the natural frequency as well as the tightening torque of the bolt [2] and the airflow around it [3].

Natural frequency regions and mode shape structures could be be calculated by simulation programs using different methods [4], [5]. However, experimental modal analysis with a low error margin proves the correlation of theoretical calculations with real environment conditions and at the same time provides more precise information about vibrational behavior of complex geometries [6].

The fundamentals of the theoretical studies on the rim began with the formation of circular plates [7]. Circular plate modeling had led to a functional path for both different geometries and different bearing conditions. Srinivasan et al. examined the rim under different bearing conditions using a commercial program based on the finite element method and supported it with experimental results [8]. To investigate reasons behind excessive vibration and noise on train wheels, Thompson examined the vibrations of the train wheels both numerically and experimentally [9]. In the Pieter's study, the effect of $4000 \mathrm{~N}$ preload on the tire on the natural frequency was investigated experimentally. It was concluded that static loading would nearly doubled the natural frequency result [10]. Then, Bertini took the vibration measurements of the points on the blades of the wing wheel with free-free conditions and compared the results with the finite element method [1]. Mohamed et al. placed coating material on the surface to reduce the noise generated by the resonance caused by the tire cavity, compared the simulation and test results [11].

While performing the modal analysis of the tires, many different methods have been carried out in the literature. Different modeling types of operating conditions can be expressed as follows: Vibration analysis of the rim in theoretical or experimental environment, radial or bias ply tire type [12], boundary conditions with rotating [13], [14], [15] or non-rotating [16] tires; free-free [17], pinned [18], rim fixed [19] or suspended $[20,21]$.

Previous studies are listed as follows; Elsalam et al. experimentally investigated how the tire effect on the wheel under different parametric conditions under different boundary conditions and pre-stresses [22]. Linghu et al. optimized the passenger vehicle steel wheel shape geometric design to extend the fatigue life in their study [23]. Nicoletti et al. created an iterative solution for the parametrically changing vehicle volume and weight by examining the effect of the change in the volume and weight of the vehicle in the early development phase for battery electric vehicles (BEVs) [24]. Sivaraj et al. presented the 
experimental modal analysis of the free and loaded wheel with dynamic and static method in their studies and recommended suitable materials according to the results [25].

In this study, our aim was to determine the natural frequencies of a non-rotating wheel under free-free boundary conditions with the Finite Element Method (FEM) and to compare the results with values obtained from an experimental impact hammer test. After that, by using ANSYS Parametric Design [26,27], an optimization was conducted on the 2019 Wheel Model to keep the natural frequency values over 200 Hertz while reducing weight and conserving fatigue strength by not exceeding maximum equivalent (von Mises) stress limit $120 \mathrm{MPa}$. The unique aspect of this study, according to other studies, was that the experimentally confirmed numerical working environment of the modal analysis in electric vehicle wheel design guides the parametric design within the specified vibration and fatigue strength limits.

\section{Material and Method}

\subsection{Experimental Settings of Impact Hammer Test}

In this study, experimental modal analysis was determined for two different wheel models, the 2018 Wheel Model (Figure 1.a) and the 2019 Wheel Model (Figure 1.b). In order to determine the natural frequency of the wheel due to its structural features, the wheels were excited by impulse hammer at certain points under freefree boundary conditions as shown in Figure 2. As shown in Figure 3.a and Figure 3.b, 66 different points were marked on the surface of the 2019 Wheel Model and 60 different points were marked on the surface of the 2018 Wheel Model and both were impacted 5 times on each of these points with the impulse hammer. The accelerometers were glued on the wheel. The material of both wheels made of Aluminum 5083. The features of 2018 and 2019 wheels were shown in Table 1.

Experimental setup consists of an uniaxial accelerometer (Brüel \& Kjaer 4533-B), a data logger (Brüel \& Kjaer-3050-B-040), an impact hammer (Brüel\&Kjaer-206-002 57129), two different Al 5083 wheels and a computer. The analog data from the accelerometer is sent to the Bruel \& Kjaer data logger which works with the Pulse LabShop software and converted into digital signals. The experimental results obtained are converted to a frequencyacceleration graph.

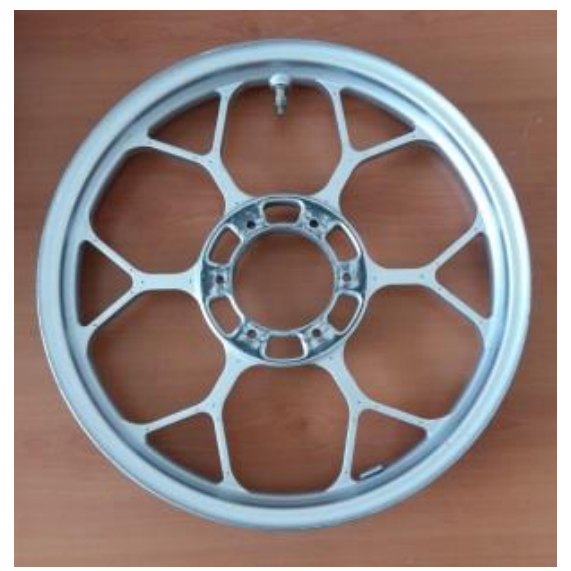

Figure 1.a. 2018 Wheel Model

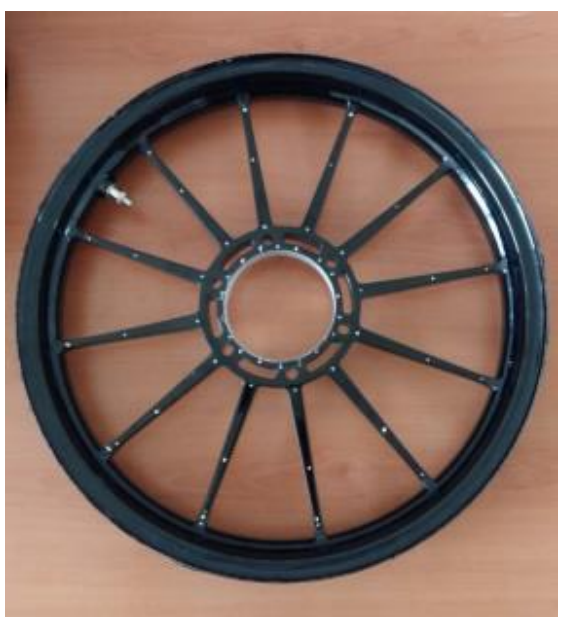

Figure 1.b. 2019 Wheel Model

Table 1. Mechanical properties of 2018 Wheel Model and 2019 Wheel Model [28]

\begin{tabular}{|c|c|c|}
\hline & $\begin{array}{l}\text { Wheel Model } \\
\text { (2018) }\end{array}$ & $\begin{array}{c}\text { Wheel Model } \\
\text { (2019) }\end{array}$ \\
\hline Density $\left(\mathrm{kg} / \mathrm{m}^{3}\right)$ & 2650 & 2650 \\
\hline Weight (kg) & 2.009 & 1.69 \\
\hline $\begin{array}{l}\text { Modulus of } \\
\text { elasticity (GPa) }\end{array}$ & 71 & 71 \\
\hline Poisson's Ratio & 0.33 & 0.33 \\
\hline
\end{tabular}




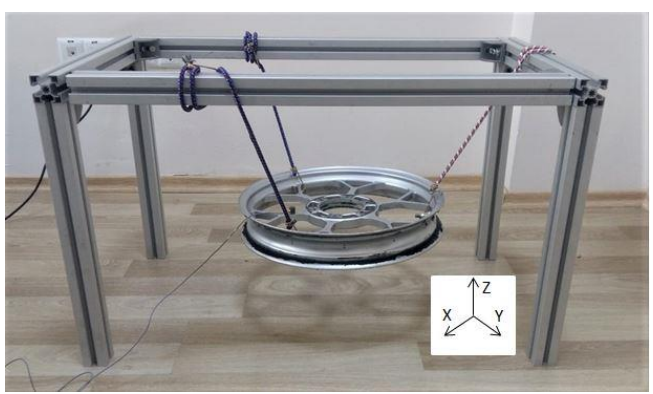

Figure 2. Experimental free-free boundary conditions setup of the 2018 Wheel model and rigid platform

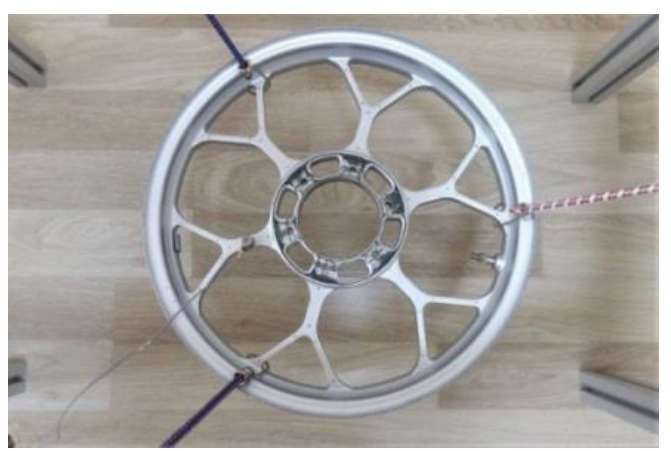

Figure 3.a. Experimental free-free boundary conditions setup of the 2018 Wheel model

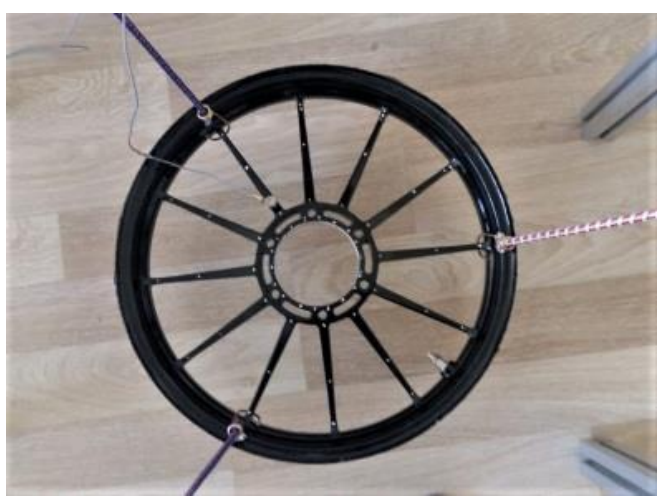

Figure 3.b. Experimental free-free boundary conditions setup of the 2019 Wheel model

\subsection{Modelling of Wheels based on Finite Element Method}

In order to perform modal analysis on the wheel, ANSYS-Modal Analysis software was used. In order to simulate the experimental setting conditions correctly, the solution was made with a 2nd order tetra element mesh method and for free-free boundary conditions, two different wheels were modeled. 2018 Wheel Model had 1254985 nodes and 783058 elements whereas 2019 Wheel Model had 213410 nodes and 114907 elements.

After evaluating the experimental and numerical results of the modal analysis, the static fatigue analysis of the 2018 and 2019 model wheel were performed. The maximum equivalent (von Mises) stress was limited to $120 \mathrm{MPa}$ for wheels of Solaris 10 Solar Car according to the operating conditions and material properties of the wheels. So in static fatigue analysis, it was recommended that the maximum equivalent (Von Mises) stress of the wheel not exceed $120 \mathrm{MPa}$ in literature. [26, 27]. As shown in the Figure 4 for the 2018 Wheel Model and the Figure 5 for the 2019 Wheel model, a 1-meter shaft drawing was added to the geometry and simulated the fatigue test environment by applying a precalculated $400 \mathrm{~N}$ force at the tip of shaft for the bending moment, this model simulated the cornering loads on the wheel which were assumed to be the most critical load on the wheel regarding fatigue strength.

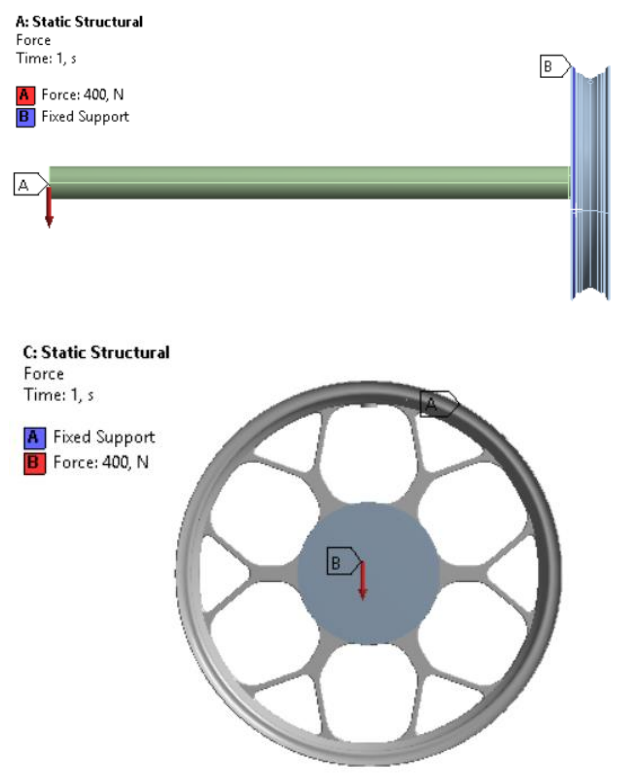

Figure 4. 2018 Wheel Model Fatigue Test Simulation in ANSYS-Static Structural 
DEÜ FMD 23(68), 689-699, 2021
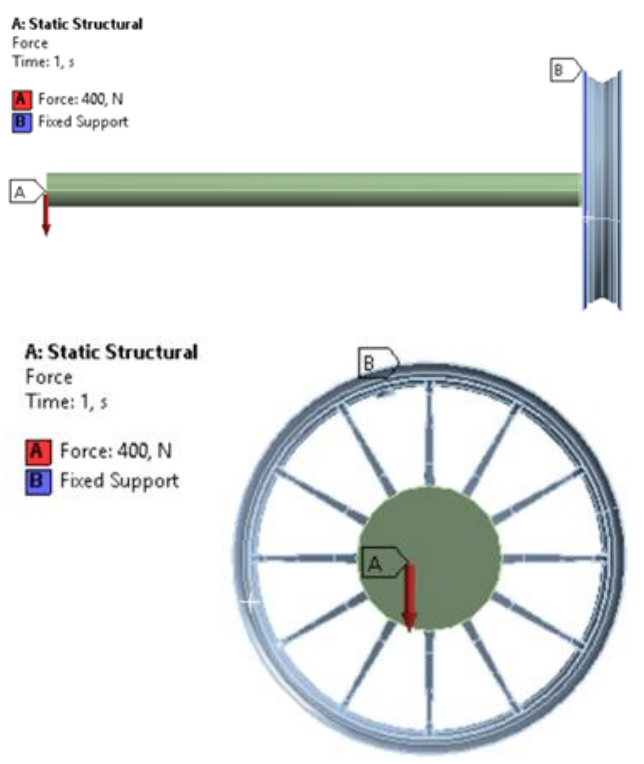

Figure 5. 2019 Wheel Model Fatigue Test Simulation at ANSYS-Static Structural

After performing the modal analysis and static fatigue analysis, parametric work were carried out. The new design parameter was designed to not exceed maximum equivalent (von Mises) stress below $120 \mathrm{MPa}$. Natural frequency values were choosen above 200 Hertz in the new design. Parametric dimensions were on the 2019 Wheel Model shown in Figure 6. Finally, static fatigue analysis was applied on the 2019 Wheel Model after parametric design geometry.

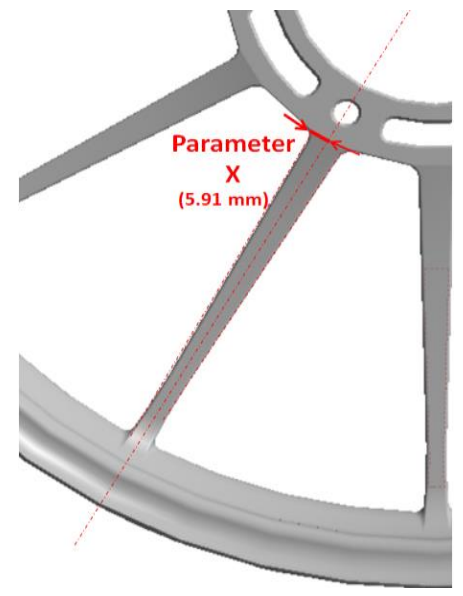

Figure 6. Parametric dimensions on the spokes of the 2019 Wheel Model

\section{Results}

In the experimental results, the results with the Coherence values closest to 1 are elected and the frequency-response graph is created with the results from each marked point. The experimental frequency - acceleration $(\mathrm{Hz}-$ $\mathrm{m} / \mathrm{Ns}^{2}$ ) graphs to determine natural frequency values are shown in Figure 7 and Figure 8. From the fact that the first 6 mode values are 0 due to free-free boundary conditions (rigid body motion), 7th mode and further is taken into consideration. Experimental and numerical results are examined up to $2000 \mathrm{~Hz}$ because of the frequency values above $2000 \mathrm{~Hz}$ become unstable in experimental set-up. The critical mode shapes in ANSYS-Modal analysis of frequency points at maximum amplitudes on the axis $\mathrm{z}$ are determined according to the experimental results of the wheel models. The numerical mode shape results are given in Figure 9 and Figure 10. The main reason of the modes considered critical mode shapes are revealed by determining the natural frequencies with experimentally observed maximum acceleration values in the z-axis. Experimental and numerical natural frequency results and error percentages are shown in Table 2 and Table 3. Since the experimental and numerical results validate each other, the changes in Table 4 are applied in the parametric design. 
DEÜ FMD 23(68), 689-699, 2021

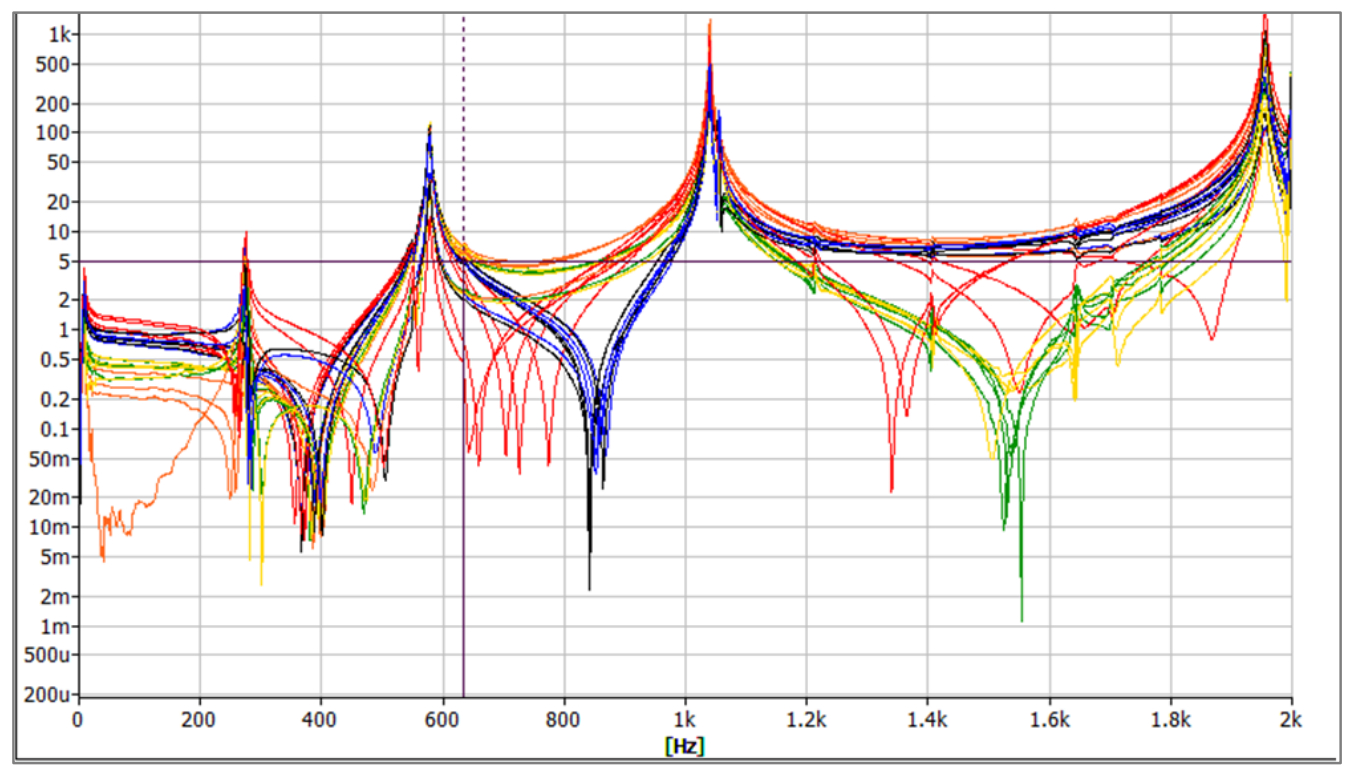

Figure 7. Frequency (Hz) - Response (m/Ns²) graph of 2018 Wheel Model (60 point measurements)

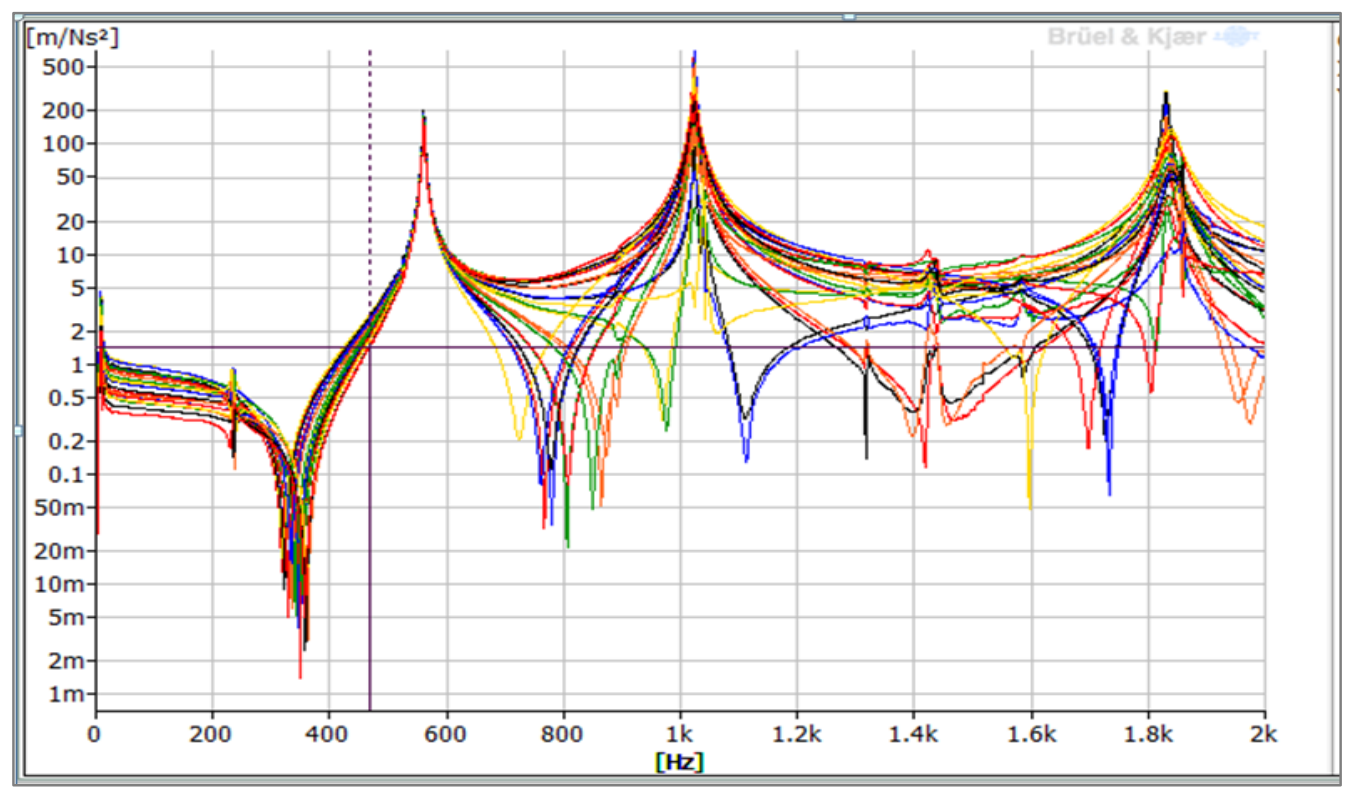

Figure 8. Frequency (Hz) - Response (m/Ns²) graph of 2019 Wheel Model (66 point measurements) 


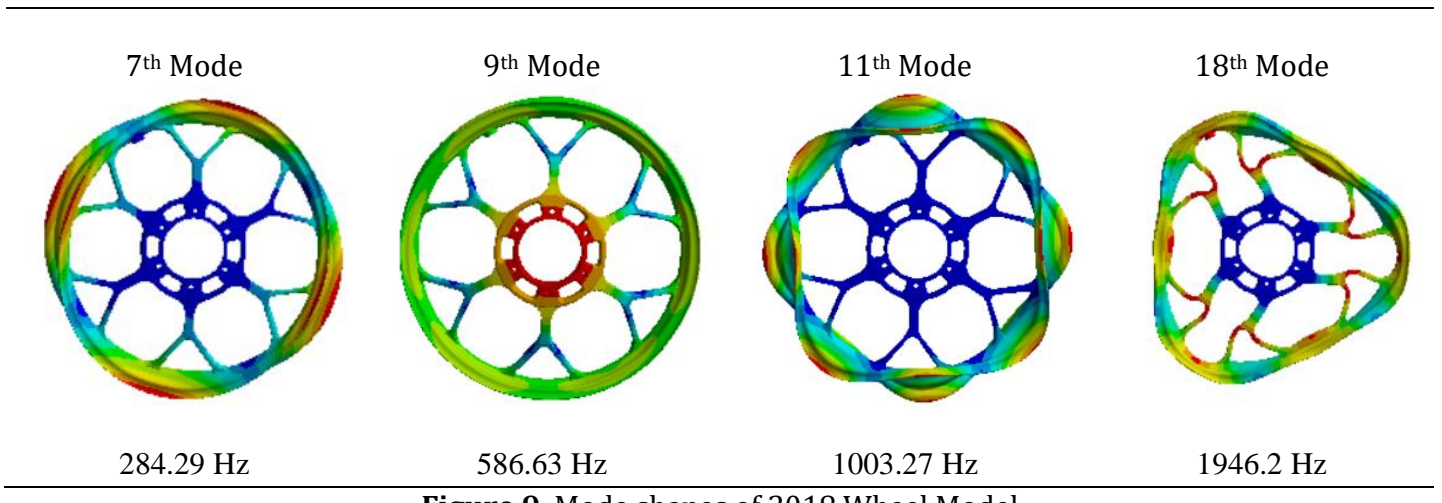

Figure 9. Mode shapes of 2018 Wheel Model

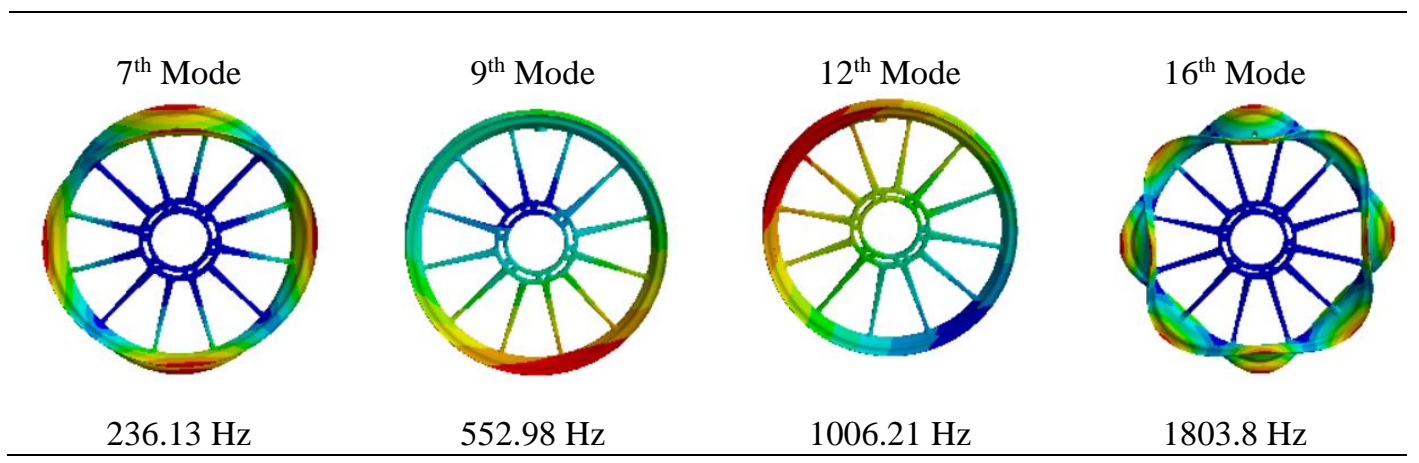

Figure 10. Mode shapes of 2019 Wheel Model

Table 2. 2018 Wheel Model Analysis Results 2018 Wheel Model Analysis Results

\begin{tabular}{cccc}
\hline & \multicolumn{2}{c}{ 2018 Wheel Model Analysis Results } \\
\hline & $\begin{array}{c}\text { Finite Element } \\
\text { Methods-Modal } \\
\text { Analysis (Hz) }\end{array}$ & $\begin{array}{c}\text { Experiment } \\
\text { al Modal } \\
\text { Analysis } \\
\text { (Hz) }\end{array}$ & $\begin{array}{c}\text { Error } \\
\text { (\%) }\end{array}$ \\
\hline $7^{\text {th }}$ Mode & 284.29 & 275 & 3.38 \\
$8^{\text {th }}$ Mode & 559.97 & 558 & 0.35 \\
$9^{\text {th }}$ Mode & 586.63 & 578 & 1.49 \\
$10^{\text {th }}$ Mode & 659.76 & 635 & 3.9 \\
$11^{\text {th } M o d e ~}$ & 1003.27 & 1037 & 3.25 \\
$12^{\text {th }}$ Mode & 1052.85 & 1055 & 0.2 \\
$13^{\text {th }}$ Mode & 1286 & 1213 & 6.01 \\
$14^{\text {th }}$ Mode & 1445.7 & 1409 & 2.6 \\
$15^{\text {th }}$ Mode & 1665.6 & 1651 & 0.88 \\
$16^{\text {th }}$ Mode & 1797.2 & 1791 & 0.34 \\
$17^{\text {th }}$ Mode & 1837.7 & ---- & --- \\
$18^{\text {th }}$ Mode & 1946.2 & 1954 & 0.4 \\
\hline
\end{tabular}

In Table 2 and Table 3, the experimental natural frequency values of the 17 th mode of the 2018 model and the 10th, 11 th and 15th modes of the 2019 model can not be compared with the numerical results. The primary reason for this is the use of a uniaxial accelerometer in an experimental environment. Since the specified mode values are not the dominant modes of the $\mathrm{z}$-axis, the natural frequency can not be found on the graph because the acceleration value remains low in the uniaxial accelerometer.

In Figure 11, the mass increases linearly as the length of the parameter $\mathrm{X}$ increases. But in Figure 12, parametric changes performed on parameter $\mathrm{X}$ affect equivalent von Mises stresses and frequency values. For this reason, Figure 11 and Figure 12 are evaluated together. 
DEÜ FMD 23(68), 689-699, 2021

Table 3. 2019 Wheel Model Analysis Results

\begin{tabular}{cccc}
\hline \multicolumn{3}{c}{ 2019 Wheel Model Analysis Results } \\
\hline & $\begin{array}{c}\text { Finite Element } \\
\text { Methods } \\
\text { Modal Analysis } \\
\text { (Hz) }\end{array}$ & $\begin{array}{c}\text { Experime } \\
\text { ntal } \\
\text { Modal } \\
\text { Analysis } \\
\text { (Hz) }\end{array}$ & $\begin{array}{c}\text { Error } \\
\text { (\%) }\end{array}$ \\
\hline $7^{\text {th }}$ Mode & 236.13 & 236 & 0.05 \\
$8^{\text {th }}$ Mode & 532.82 & 526 & 1.28 \\
$9^{\text {th }}$ Mode & 552.98 & 561 & 1.42 \\
$10^{\text {th }}$ Mode & 829.12 & ---- & --- \\
$11^{\text {th }}$ Mode & 894.77 & ---- & ---- \\
$12^{\text {th }}$ Mode & 1006.21 & 1023 & 1.64 \\
$13^{\text {th }}$ Mode & 1324.2 & 1318 & 0.47 \\
$14^{\text {th }}$ Mode & 1332.5 & 1440 & 7.46 \\
$15^{\text {th }}$ Mode & 1723.3 & ---- & ---- \\
$16^{\text {th }}$ Mode & 1803.8 & 1831 & 0.989 \\
\hline
\end{tabular}

Figure 11. Mass change results depending on the parameter $\mathrm{X}$

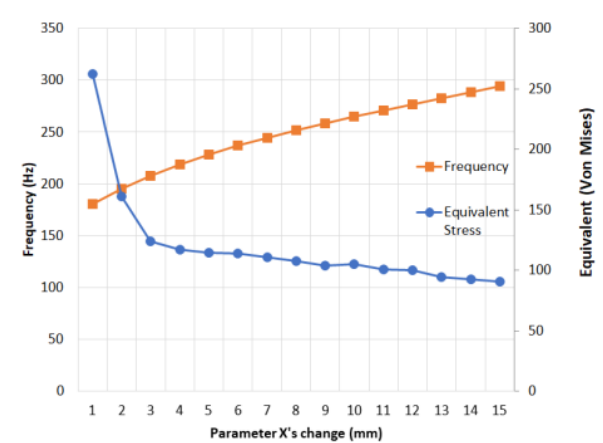

Figure 12. Equivalent von Mises and frequency results depending on the parameter $\mathrm{X}$

Table 4. Parametric values of 2019Wheel

\begin{tabular}{|ccccc}
\hline & $\begin{array}{r}\text { Parame } \\
\text { ters of } \\
\text { X (mm) }\end{array}$ & $\begin{array}{c}\text { Equivalent } \\
\text { Stress } \\
\text { (MPa) }\end{array}$ & $\begin{array}{c}\text { Frequency } \\
\text { (7th mode) } \\
\text { (Hz) }\end{array}$ & $\begin{array}{c}\text { Mass } \\
(\mathrm{kg})\end{array}$ \\
\hline DP 0 & 5.91 & 119.3 & 236.13 & 1.69 \\
\hline DP 1 & 1 & 262.21 & 180.54 & 1.39 \\
\hline DP 2 & 2 & 160.9 & 195.56 & 1.45 \\
\hline DP 3 & 3 & 124.24 & 208.04 & 1.51 \\
\hline DP 4 & 4 & 116.9 & 218.82 & 1.58 \\
\hline DP 5 & 5 & 114.38 & 228.33 & 1.64 \\
\hline DP 6 & 6 & 113.88 & 236.88 & 1.70 \\
\hline DP 7 & 7 & 110.47 & 244.68 & 1.76 \\
\hline DP 8 & 8 & 107.9 & 251.88 & 1.82 \\
\hline DP 9 & 9 & 104.02 & 258.57 & 1.89 \\
\hline DP10 & 10 & 105.04 & 264.91 & 1.95 \\
\hline DP 11 & 11 & 100.83 & 270.96 & 2.01 \\
\hline DP 12 & 12 & 100.16 & 276.85 & 2.07 \\
\hline
\end{tabular}

Equivalent Stress (MPa), frequency $(\mathrm{Hz})$, mass (kg) change depending on the parametric design of parameter 1 , which is indicated with the number ' 1 ' in Figure 6, is shown in Table 4. The expression parametric design 'DP 0' shows the numerical values of the 2019 model wheel produced. The values shown from DP 1 to DP 12 refer to the results which obtained the parameter X length changes from $1 \mathrm{~mm}$ to 12 $\mathrm{mm}$. The initial mass value of the 2019 Wheel Model is $1.69 \mathrm{~kg}$. While it is aimed to reduce the mass of the wheel, it is taken notice of the equivalent stress results are less than $120 \mathrm{MPa}$ $[26,27]$ and the 7 th frequency values are greater than $200 \mathrm{~Hz}$. Although there are decreases in the mass of the wheel in the DP1 and DP2 parameters, these parameters are not accepted due to the fact that the Equivalent stress values are greater than $120 \mathrm{MPa}$ and the 7 th frequency values are less than $200 \mathrm{~Hz}$. In the DP 3 parameter, the 7 th frequency value increases above $200 \mathrm{~Hz}$, but it is not accepted because the Equivalent stress value is over 120 
DEÜ FMD 23(68), 689-699, 2021

MPa. For the remaining parameters, DP4 has the least value of mass. It is below $120 \mathrm{MPa}$ and the frequency value is above 200 Hertz. As a result of the parametric design, the DP 4 parameter with a length of $4 \mathrm{~mm}$ gave the most ideal result and the mass decreased by approximately $6.5 \%$ while the equivalent stress decreased by approximately 2\%. The new geometry's Equivalent von Mises Stress results from the parametric design is given in Figure 13. The natural frequency values of the new geometry in 7 th mode and above are given in Table 5. It is observed that the natural frequency values of the new wheel are suitable with the natural frequency values above 200 Hertz starting from the 7 th mode.

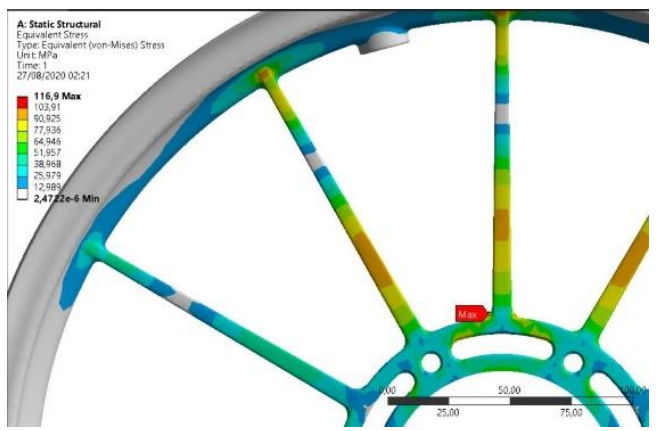

Figure 13. Equivalent von Mises Stress Results of 2019 Wheel Model after parametric design

Table 5. Finite Element Methods Modal Analysis results of 2019 Wheel Model after parametric design

\begin{tabular}{cc}
\hline Modes & $\begin{array}{c}\text { Finite Element Methods } \\
\text { Modal Analysis }(\mathrm{Hz})\end{array}$ \\
\hline $7^{\text {th }}$ Mode & 218.82 \\
$8^{\text {th }}$ Mode & 506.48 \\
$9^{\text {th }}$ Mode & 616.72 \\
$10^{\text {th }}$ Mode & 876.64 \\
$11^{\text {th }}$ Mode & 985.7 \\
$12^{\text {th }}$ Mode & 1280.4 \\
$13^{\text {th }}$ Mode & 1308.6 \\
\hline
\end{tabular}

\section{Discussion and Conclusion}

Wheels of Solaris 10 Solar Car were considered in this study. The numerical and experimental analysis under the free-free boundary conditions were carried out. It was found that the experimental results validated numerical solutions. Further, the parametric study was performed. Several conclusions were drawn from this study, as follows:

1. ANSYS-Modal Analysis results, which are computed using finite element method and the natural frequency results obtained from the impact hammer test, have been obtained close to each other with a maximum error of $7.46 \%$. In this way, numerical and experimental frequencies of the model are observed. At the same time, numerical mode shapes with greater amplitude values are determined.

2. The 7 th mode frequencies of the 2018 Wheel Model and the 2019 Wheel Model are obtained above $200 \mathrm{~Hz}$. The target of the 7 th mode frequency result of the wheel obtained by parametric design to be above 200 Hertz has been completed.

3. Mass decreased by $6.5 \%$ and maximum equivalent von Mises stress is decreased by $2 \%$. A new design with reduced mass is formed, paying attention to the fact that the fatigue result of the changed parameters does not exceed $120 \mathrm{MPa}$.

Thanks to this study, the natural frequency values of Wheels of Solaris 10 Solar Car examined with numerically and experimentally and the results obtained were in good agreement. In this study, a unique parametric design is made on the geometry based on the data obtained as a contribution to the literature. In future studies, the modal analysis of 'Wheels of Solaris 10 Solar Car' can be examined with tires and different bearing conditions, results can be interpreted with the working conditions of the Solaris 10 Solar Car vehicle. 


\section{Acknowledgement}

The authors would like to thank Cevher Wheels Company, Manisa Celal Bayar University and Dokuz Eylül University-Solaris Car Team for the permission to publish this article.

\section{References}

[1] Bertini,L., Monelli,B., Neri, P., Santus, C., Guglielmo, A. 2014. Robot Assisted Modal Analyis on a Stationary Bladed Wheel, Proceedings of the ASME 2014 12th Biennial Conference on Engineering Systems Design and Analysis. DOI: 10.1115/ESDA2014-20636

[2] Sun-Min Kim, Jae-Hoon Ha, Sung-Ho Jeong, Sun-Kyu Lee, 2001. Effect of joint conditions on the dynamic behavior of a grinding wheel spindle, International Journal of Machine Tools \& Manufacture, Volume. 41,p. 1749-1761 . DOI: 10.1016/S08906955(01)00040-2

[3] Scavuzzo, R. W., Charek, L. T ., Sandy, P. M. and Shteinhauz, G. D. 1994. Influence of Wheel Resonance on Tire Acoustic Cavity, Journal of Passenger Cars, Volume. 103, p. 643-648. DOI: $10.4271 / 940533$

[4] Hebba, M. S., Dabair, M. 2019. Static Structural, Modal and Harmonic Analysis of Alloy Car Wheel Rim using ANSYS Workbench, International Journal of Engineering Research \& Technology (IJERT) Volume. 8, p.599-611. DOI: IJERTV8IS070226

[5] Shwetabh Suman, Abhimanyu Abrol, J. and Ravi, K.2.17. Impact and Modal Analysis for Different Alloy Wheel, IOP Conference Series: Materials Science and Engineering, Volume. 263, p. 1-10. DOI: 10.1088/1757-899X/263/6/062074

[6] Akbar, M. M., Farahani, M. 2018. Modal Analysis of a Non-rotating Inflated Tire using Experimental and Numerical Methods,International Journal of Engineering Innovation \& Research, Volume. 7, p. 15-21. ISSN: 2277 - 5668.

[7] Leissa, A. W. 1969. Vibration of plates, NASA OHIO STATE UNIV COLUMBUS, $160 p$.

[8] Srinivasan, V., Swarnamani S., Ramamurti, V. 1980. Free Vibration of a Wheel, Journal of Sound and Vibration, Volume. 70(3),p. 461-462. DOI: PASCAL8130013818

[9] Thompson, D.J. 1993. Wheel-rail Noise Generation, Part II: Wheel Vibration, Journal of Sound and Vibration, Volume. 161, p. 401-419. DOI: 10.1006/jsvi.1993.1083

[10] Pieters, R. 2007. Experimental Modal Analysis of an Automobile Tire under Static Load, Eindhoven: Technische Universitei, Traineeship Report, Eindhoven.

[11] Zamri Mohamed, Xu Wang, 2015. A Study of Tyre Cavity Resonance and Noise Reduction Using Inner
Trim, Mechanical Systems and Signal Processing, Volumes. 50-51, p. 498-509. DOI: 10.1016/j.ymssp.2014.05.044

[12] Chiesa, A., Oberto, L. and Tamburini, L. 1964. Transmission of Tyre Vibrations, Automobile Engineer, Volume:54 (3), p. 520-530.

[13] Gong, S., Savkoor, A., and Pacejka, H. 1993. The Influence of Boundary Conditions on the Vibration Transmission Properties of Tires, SAE Paper 931280. DOI: $10.4271 / 931280$

[14] Senjanović, I., Alujević, N., Ćatipović, I., Čakmak, D., \& Vladimir, N. 2018. Vibration analysis of rotating toroidal shell by the Rayleigh-Ritz method and Fourier series, Engineering Structures, Volume: 173, p. 870-891. DOI: 10.1016/j.engstruct.2018.07.029

[15] Kindt, P., Sas, P., \& Desmet, W.2009. Measurement and Analysis of Rolling Tire Vibrations, Optics and Lasers in Engineering Volume. 47, p. 443-453. DOI: 10.1016/j.optlaseng.2008.06.017

[16] Potts, G. R., Bell, C. A., Charek, L. T., \& Roy, T. K. 1977. Tire Vibrations, Tire Science and Technology, Volume: 5, p. 202-225. DOI: 10.2346/1.2167240

[17] Chittilla, K., Yeola, Y., Tiwari, A., \& Rajamanickam, R. 2013. Effect of Excitation Methods on Experimental Modal Analysis of Passenger Car Tire, SAE Technical Paper 2013-01-2854. DOI: 10.4271/2013-01-2854

[18] Maes, J., \& Sol, H. 2003. A Double Tuned Rail Damper-Increased Damping at the Two First Pinned-pinned Frequencies, Journal of Sound and Vibration, Volume. 267, p. 721-737. DOI: 10.1016/S0022-460X(03)00736-3

[19] Richards, T. R., Charek, L. T., \& Scavuzzo, R. W. 1986. The Effects of Spindle and Patch Boundary Conditions on Tire Vibration Modes, SAE Transactions, Volume. 95, p. 19-30.

[20] Kung, L. E., Soedel, W., \& Yang, T. Y.1986. On the Dynamic Response at the Wheel Axle of a Pneumatic Tire, Journal of Sound and Vibration, Volume: 107, pp. 195-213. DOI: 10.1016/0022-460X(86)90232-4

[21] Zegelaar, P. W. A.1997. Modal Analysis of Tire InPlane Vibration, SAE TECHNICAL PAPER SERIES, No:971101.

[22] A. Abd_Elsalam, M.A. Gohary, H.A. El-Gamal.2017. Modal analysis on tire with respect to different parameters, Alexandria Engineering Journal, Volume: 6, p.345-357. DOI: 10.1016/j.aej.2016.09.022

[23] Kezhi Linghu, Baoliang Xiao, Dawei Zhang, Xiaolin Li, Fengqin Wang and Zhipeng Wang.2018. Shape Optimization of Passenger Vehicle Wheel on Fatigue Failure, IOP Conf. Series: Materials Science and Engineering, Volume. 381, p.1-7, DOI: 10.1088/1757-899X/381/1/012025

[24] Lorenzo Nicoletti , Andrea Romano , Adrian König , Ferdinand Schockenho and Markus Lienkamp. 2020. Parametric Modeling of Mass and Volume Effects for Battery Electric Vehicles, with Focus on the Wheel Components, Word Electric Vehicle Journal, Volume.63, p.1-24, DOI: 
10.3390/wevj11040063

[25] Sivaraj, S. Nagendharan, S. Mohanavel ,V.2020 Experimental investigation on wheel natural frequency performance using modal analysis in free and loaded condition, Materials Today: Proceedings, p. 1-9. DOI: 10.1016/j.matpr.2020.04.546

[26] Bosi, C., Garagnani, G. L., \& Tovo, R. 2002. Fatigue Properties of a Cast Aluminium Alloy for Rims of Car Wheel, Metallurgical Science and Technology, Volume. 20, p. 3-8.

[27] James M.N., D.J. Hughes, D.G. Hattingh, G. Mills, P.J. Webster. 2009. Residual Stress and Strain in MIG Butt Welds in 5083-H321 Aluminium: As-welded and Fatigue Cycled, International Journal of Fatigue, Volume. $31, \mathrm{p} .28: 40$, 10.1016/i.ijfatigue.2008.04.010

[28] T.B. Korkut, E. Armakan, O. Ozaydin, K. Ozdemir, A. Goren.2020. Design and comparative strength analys is of wheel rims of a lightweight electric vehicle using Al6063 T6 and Al5083 aluminium alloys. Journal of Achievements in Materials and Manufacturing Engineering. Volume.99, p.57-63. DOI:10.5604/01.3001.0014.1776 